\title{
Arendtian Inquiry, Philosophical Method, and Parental Responsibility
}

Natasha Levinson

Kent State University

In "Raising a Human," Stephanie Mackler makes tangible Arendt's rather abstract exhortation that the people charged with educating children take responsibility for the world as it is by alerting us to the small and seemingly inconsequential ways in which a concern with the world enters into daily life: "Why is the road bumpy?" The parent stakes out a position: "because they didn't fix it." Mackler explains that it was only after the fact, as her son repeated her explanation each time they drove down the bumpy road, that she started to wonder whether she had in fact represented the world adequately: "I found myself questioning whether I had been too unsympathetic to the city and its workers and whether the real issue that I should appreciate is the inevitable demise of the physical world. After all, don't I want my child to understand that all material things eventually decay?”

Macklerinvites us to think about these seemingly small moments between a parent and a child as existentially weighty in a distinctively Arendtian way that puts her rumination on parental responsibility at odds with the overall thrust of contemporary discourses on parenting. As Judith Suissa and Stefan Ramaekers show in The Claims of Parenting, these discourses tend to reduce parenting to a concern with the child's psychological and physical development. ${ }^{1}$ This echoes concerns expressed by Arendt, who takes parents as well as teachers to task for relinquishing their responsibilities to the world and bringing about the crisis in authority that she takes to be the root of the crisis in education: "Human parents," writes Arendt, "have not only summoned their children into life through conception and birth, they have simultaneously introduced them into a world. In education, they assume responsibility for both, for the life and development of the child and for the continuance of the world."'2 Like Arendt, Mackler regards taking responsibility for the world to be "a central task of being a parent," but 
she puts an interesting twist on Arendt's admonition by showing how everyday engagements with children inadvertently put parents in the position of assuming this responsibility. The world is all around us, Mackler seems to say; we are immersed in it even though parenting discourses might lead us to lose sight of it - while political theory, on the other hand, might lead us to take a rather lofty view of things. This reversal is a very interesting methodological point that I take to be at the heart of what she refers to as her "philosophical-anthropological and existential approach" to the question of what it means to take responsibility for the world and how this taking responsibility happens.

The cornerstones of an Arendtian anthropology are the twin conditions of natality and plurality. Arendt calls these "the facts" of natality and plurality, and in an Augustinian vein, she holds that the right attitude to these conditions of human life on earth is gratitude, as well as a certain vigilance on the part of human beings. ${ }^{3}$ Although natality and plurality constitute the conditions under which life on earth has been given to us, neither condition is guaranteed. Both are easily quashed and need to be protected. On this view, there is nothing automatic about the parent's taking stock of the world in response to their children's provocations. Herein lies the existential-and educational - dimension of Mackler's approach. The parent has a decision to make. They can act in a way that protects natality - perhaps by bending a little to the child mourning the dead worm in the driveway - but they also have to recognize the condition of plurality that makes being more or less on time to the dentist a sign of one's willingness to share the world with others. The Arendtian parent has to balance natality with plurality. The child might be new, but they are introduced to an old world, with established mores and social agreements that the parent must decide to endorse, reject, or revise. These existential decisions have a threefold consequence because they shape the parent, the child, and world that holds them together.

Mackler construes the sorts of seemingly innocuous exchanges with her children as occasions to enact, in very concrete ways, what it means to take responsibility for the world. This is not "mere thinking" but judgment, and perhaps even a type of action. As Mackler puts it, "the parent has to make a 
decision about how to represent the world.” Importantly, her decision - whether to cajole her daughter into the car or to explain the bumps in the road in this way rather than that - is not the end point of the exchange. As Mackler's rumination on her initial response to her son's question indicates, her attempt to explain why the road is bumpy is repeated back to her in ways that continue to hold her accountable: has she done justice to the world? Being the good philosopher of education, she may well find herself unravelling each response in her head subsequently as her child repeats her answer, at once alerting her to her authority as a parent and provoking a certain anxiety about it. This doesn't change the fact of her initial decision or what it says about her position as representative of a world that she "didn't make and might wish were other than it is."

Here's what I take to be significant about Mackler's suggestive paper. First, she makes a case for extending Arendt's conception of education to parenting by showing how a concern for the world emerges in the everyday acts of being a parent. Second, she shows how these engagements not only position parents awkwardly between the newness of the child and the pressures of the existing world, but also corner parents into taking a side. Third, judging from her two illustrative examples ("Why is the road bumpy?" and "The worm died"), it appears that parents tend to side with the world, which makes parenting a necessarily conservative enterprise (and by the way, in the current political climate of the U.S., there is a profound virtue in this stabilizing orientation to the world). Fourth, her approach to Arendtian inquiry puts forward a suggestive rethinking of the small but striking ways in which children prompt parents into taking responsibility for the world. Finally - although this might be too strong a claim - it seems to me that in an important way, Mackler's Arendtian inquiry shows how Arendtian themes become evident in the act(s) of being a parent. They are not simply "applied" to the analysis of parenting. Instead of lambasting parents with another set of exhortations about the need to take responsibility for the world, or giving parents prescriptions about how to do so, she suggests that the intersubjective act(s) of raising a child have the capacity to prompt this reorientation to the world. Now, it's true that in a certain 
sense, from an Arendtian perspective, Mackler's initial response - "they didn't fix it" - fails to take responsibility for the world. A more Arendtian response might be something like this: "Because we don't pay enough taxes for the city workers to fix our roads." But this sort of prescriptivism is precisely beside the point. As I see it, Mackler's paper suggests that, from an existential point of view, to be a parent is at least potentially to be invited into the world, in ways that prompt us to think about who we are and what we stand for. While new parents might think that these big things are decided at the beginning, in fact, as Mackler's everyday encounters show, it is the small moments that alert us to the things we have yet to figure out in relation to the children we love and the world we hope to protect, and our off the cuff responses are the continual catalyst for doing so. I appreciate Mackler's attention to what she calls Arendt's "philosophical-anthropology" and I very much look forward to seeing this aspect of Arendt's thinking worked out further in relation to philosophical perspectives on "raising humans." There is something in this formulation in Mackler's title that draws attention to the vulnerability and bewilderment of the exercise - the small shocks that we experience when we realize we are not the self-certain parents we would perhaps like to be. These unsettling moments make parenting a generative and educative experience for parents and children alike.

1 Stefan Ramaekers and Judith Suissa, The Claims of Parenting: Reasons, Responsibility, and Society (Netherlands: Springer, 2012). See also Stefan Ramaekers and Judith Suissa, "What All Parents Need to Know? Exploring the Hidden Normativity of the Language of Developmental Psychology in Parenting," Journal of Philosophy of Education 46, no. 3 (2012): 352-369.

2 Hannah Arendt, "The Crisis in Education," in Between Past and Future: Eight Exercises in Political Thought (New York: Penguin Books, 1977), 182.

3 Hannah Arendt, The Human Condition (Chicago: The University of Chicago Press, 1958), 8-10. 